University of New Hampshire

University of New Hampshire Scholars' Repository

4-30-2010

\title{
The significance of local water resources captured in small reservoirs for crop production - A global-scale analysis
}

\author{
Dominik Wisser \\ Universitat Bonn \\ Steve Frolking \\ University of New Hampshire - Main Campus, steve.frolking@unh.edu \\ Ellen M. Douglas \\ University of Massachusetts, Boston \\ Balazs M. Fekete \\ City College of New York \\ Andreas H. Schumann \\ Ruhr-Universitat Bochum
}

See next page for additional authors

Follow this and additional works at: https://scholars.unh.edu/earthsci_facpub

\section{Recommended Citation}

Dominik Wisser, Steve Frolking, Ellen M. Douglas, Balazs M. Fekete, Andreas H. Schumann, Charles J. Vörösmarty, The significance of local water resources captured in small reservoirs for crop production A global-scale analysis, Journal of Hydrology, Volume 384, Issues 3-4, 30 April 2010, Pages 264-275, ISSN 0022-1694, http://dx.doi.org/10.1016/j.jhydrol.2009.07.032.

This Article is brought to you for free and open access by the Earth Sciences at University of New Hampshire Scholars' Repository. It has been accepted for inclusion in Earth Sciences Scholarship by an authorized administrator of University of New Hampshire Scholars' Repository. For more information, please contact Scholarly.Communication@unh.edu. 


\section{Authors}

Dominik Wisser, Steve Frolking, Ellen M. Douglas, Balazs M. Fekete, Andreas H. Schumann, and Charles Vorosmarty 


\title{
The significance of local water resources captured in small reservoirs for crop production - A global-scale analysis
}

\author{
Dominik Wisser $^{\mathrm{a}, *}$, Steve Frolking ${ }^{\mathrm{a}}$, Ellen M. Douglas ${ }^{\mathrm{b}}$, Balazs M. Fekete ${ }^{\mathrm{c}}$, Andreas H. Schumann ${ }^{\mathrm{d}}$, \\ Charles J. Vörösmarty ${ }^{\mathrm{c}}$
}

a Institute for the Study of Earth, Oceans, and Space, University of New Hampshire, Durham, NH, USA

${ }^{\mathrm{b}}$ Dept. of Environmental, Earth and Ocean Sciences, University of Massachusetts, Boston, MA, USA

${ }^{\mathrm{c}}$ Dept. of Civil Engineering, City College of New York, New York, NY, USA

${ }^{\mathrm{d}}$ Institute of Hydrology, Water Resources Management and Environmental Engineering, Ruhr-Universität Bochum, Germany

\section{A R T I C L E I N F O}

\section{Keywords:}

Small reservoirs

Global modelling

Food security

Crop yield

\begin{abstract}
S U M M A R Y
Rainwater harvesting, broadly defined as the collection and storage of surface runoff, has a long history in supplying water for agricultural purposes. Despite its significance, rainwater harvesting in small reservoirs has previously been overlooked in large-scale assessments of agricultural water supply and demand. We used a macroscale hydrological model, observed climate data and other physical datasets to explore the potential role of small, localized rainwater harvesting systems in supplying water for irrigated areas. We first estimated the potential contribution of local water harvesting to supply currently irrigated areas. We then explored the potential of supplemental irrigation applied to all cropland areas to increase crop evapotranspiration (or green water flow), using locally stored surface runoff in small reservoirs for different scenarios of installed reservoir capacity. The estimated increase in green water flow varied between 623 and $1122 \mathrm{~km}^{3} \mathrm{a}^{-1}$. We assessed the implications of this increase in green water flows for cereal production by assuming a constant crop water productivity in areas where current levels of crop yield are below global averages. Globally, the supplemental irrigation of existing cropland areas could increase cereal production by $\sim 35 \%$ for a medium variant of reservoir capacity, with large potential increases in Africa and Asia. As small reservoirs can significantly impact the hydrological regime of river basins, we also assessed the impacts of small reservoirs on downstream river flow and quantified evaporation losses from small reservoirs.
\end{abstract}

(c) 2009 Elsevier B.V. All rights reserved.

\section{Introduction}

Global water demand for food production for a growing world population is expected to rise and part of the increase will be accomplished under increasing water scarcity. Rockström et al. (2007) estimate that an additional $1850 \mathrm{~km}^{3} \mathrm{y}^{-1}$ of freshwater will be needed to produce enough food to eradicate hunger in 92 developing countries by 2015 , and suggest that $270 \mathrm{~km}^{3} \mathrm{y}^{-1}(15 \%)$ of that amount can be met by conventional irrigation water. A significant contribution of increased food production levels would have to come from an increase in the so-called "green" water flows, which consist of the consumptive water used (evapotranspiration) in biomass production or plant growth. Enhancing the productivity of rainfed cropland areas using supplemental small-scale irrigation infrastructure is therefore an important tool to increase green

\footnotetext{
* Corresponding author. Address: Water Systems Analysis Group, University of New Hampshire. 8 College Road., Duham, NH 03820, USA. Tel.: +1 603862 2706; fax: +1 6038620587 .

E-mail address: dominik.wisser@unh.edu (D. Wisser).
}

water flows, particularly given growing environmental and social concerns about large-scale irrigation projects (Fraiture et al., 2007) that rely on abstractions from groundwater and river flow (so-called "blue" water).

Rainwater harvesting for local irrigation can broadly be defined as the collection and storage of rainy season precipitation for productive purposes, and includes the collection of water from developed land, ephemeral streams, and hillslopes (Kahinda et al., 2008; Ngigi et al., 2005). Intercepted local runoff is at the interface of green and blue water, because it is captured and applied to croplands (green water) before it becomes river water and would otherwise become part of a larger irrigation (blue water) scheme or part of the soil moisture stock (green water). Rainwater harvesting is an ancient concept (Oweis and Hachum, 2006; Pandey et al., 2003), and can be dated back to the Neolithic Age in the mountains in southern Jordan (Bruins et al., 1986). Rainwater harvesting has been a key to securing livelihoods and increasing crop yields in many civilizations, and the storage of water has become a key strategy against water scarcity under changing climate conditions (Gunnell and Krishnamurthy, 2003; Pandey et al., 2003). Small 
reservoirs have proved to be an essential tool for managing scarce water resources and providing supplemental irrigation and thereby to increase and stabilize crop yields (Oweis and Hachum, 2006). There are no global data sets quantifying area, volume, or irrigation capacity of small reservoirs.

For the purpose of this study we refer to rainwater harvesting as the collection of surface runoff from non-irrigated areas for application to adjacent irrigated croplands (Qadir et al., 2007). To distinguish systems that serve agricultural purposes, Bruins et al. (1986) suggested the term 'runoff farming'. Runoff farming systems include small reservoirs, ponds, cisterns, tanks, and other microstorage facilities that typically supply a very small area; in India, for example, microstorage facilities typically supply water to crop areas of 1.5-50 ha (Gunnell and Krishnamurthy, 2003). Manually dug farm pond storage capacity generally ranges between 50 and $1000 \mathrm{~m}^{3}$; storage capacity is typically $50-100 \mathrm{~m}^{3}$ for underground water tanks (Ngigi, 2003).

Despite their importance, small reservoirs and farm ponds have been overlooked in large-scale hydrological assessments like the one presented here. The traditional focus of efforts to increase food security has been on large-scale irrigation projects that rely on blue water (Bruins et al., 1986). In sub-Saharan Africa, most of these large-scale irrigation projects have been proven to be costly and environmentally unsustainable (Ngigi, 2003). In the last 1020 years, small storage facilities received increased attention, as their role in alleviating poverty has been recognized ( $\mathrm{Li}$ et al., 2000; Oweis et al., 2004). Downing et al. (2006) suggested that the annual growth rate in the number of small reservoirs could be as high as $60 \%$ in dry regions of India, where an estimated 120,000 small reservoirs supply irrigation water to more than 4.12 Mha; this is about $37 \%$ of the regional irrigated area (Anbumozhi et al., 2001). In India as a whole, SRs supply an estimated $20 \%$ of irrigated area ( $\mathrm{Li}$ and Gowing, 2005). Senay and Verdin (2004) explored the potential of rainwater harvesting in Africa by producing a number of water harvesting index maps at a spatial resolution of $10 \mathrm{~km}$, based on the SCS Curve Number Method, remotely-sensed daily precipitation and other physical datasets.

Small reservoir based irrigation systems require less effort and resources for construction, maintenance, and operation, and can be more flexible than conventional, large-scale, 'blue water' based systems that typically require considerable investments in infrastructure. Furthermore, small reservoir systems can have minimal conveyance losses, can be adapted for a number of different conditions, and require little operational training (Qadir et al., 2007). They can facilitate the expansion of irrigated areas in regions with topographical conditions that makes large-scale irrigation projects difficult to develop ( $\mathrm{Li}$ et al., 2000). The optimal design of those storage facilities depends on both the available water that could potentially be collected and the amount of water that is needed in irrigated areas and can be estimated using water balance modeling approaches. Water balance modeling and GIS based approaches have previously been used to design and simulate the performance of individual runoff farming systems (Li and Gowing, 2005; Srivastava, 1996), cascades of reservoir systems (Jayatilaka et al., 2003), or watersheds (Mbilinyi et al., 2007).

The objective of this paper is twofold: first we assess the geography of the potential contribution of small reservoirs to supplying irrigation water and estimate the distribution and density of such structures, using a macroscale hydrological model and observed climate drivers applied to global croplands. We then estimate potential increases in green water fluxes in all cropland areas that could be achieved by the collection and storage of surface runoff for supplemental irrigation during critical crop growth periods. The potential implications of these increases of green water flux for global food production are assessed by using observed crop water productivity data and global crop production datasets. We also assess downstream impacts of increased use of small reservoirs.

\section{Data and methods}

The $W B M_{\text {plus }}$ model

To estimate the amount of water required for irrigation purposes and the amount of water that could potentially be collected from local surface runoff, we used a modified version of the WBM model (Vörösmarty et al., 1998), the $\mathrm{WBM}_{\text {plus }}$ model. $\mathrm{WBM}_{\text {plus }}$ calculates components of the hydrological cycle on a grid-cell by gridcell basis by partitioning each grid cell (30 min spatial resolution in this study; about $50 \mathrm{~km}$ at the equator) into an irrigated and a nonirrigated fraction and computing the water and vapor fluxes in each grid cell as the area-weighted sum of the two components.

$\mathrm{WBM}_{\text {plus }}$ was recently used to simulate uncertainty and variability in global irrigation water requirements (Wisser et al., 2008) using two climate datasets and two irrigated area maps and yielded results consistent with reported irrigation water withdrawals when compared with national and international statistics at the country level.

\section{Irrigation in $W B M_{\text {plus }}$}

Irrigation water demand in the irrigated fraction of the grid cell is computed for individual crops, distributed globally using global data sets of croplands and aggregated crop types. The approach implemented in $\mathrm{WBM}_{\text {plus }}$ to estimate crop evapotranspiration for irrigated crops is the crop coefficient method (Allen et al., 1998) which computes crop evapotranspiration $E T_{c}\left(\mathrm{~mm} \mathrm{~d}^{-1}\right)$ as the product of reference evapotranspiration $E T_{0}\left(\mathrm{~mm} \mathrm{~d}^{-1}\right)$ and a crop coefficient $k_{c}$. The crop coefficient represents crop physiological parameters and varies with time. Irrigation water $I_{\text {net }}\left(\mathrm{mm} \mathrm{d}^{-1}\right)$ is applied such that the soil water is refilled to its holding capacity whenever the soil moisture drops below a crop-dependent critical threshold. A simple soil moisture accounting approach is applied to calculate daily values of soil moisture as a function of precipitation and crop evapotranspiration.

For paddy rice crops, an additional amount of water is needed to maintain a constant flooding depth $(50 \mathrm{~mm})$ throughout the growing season, and for replenishing water that percolates into the groundwater at a constant rate, depending on the grid cell soil drainage class (FAO/UNESCO, 2003). Percolation rates were estimated between $8 \mathrm{~mm} \mathrm{~d}^{-1}$ for 'extremely well drained soils' and $2 \mathrm{~mm} \mathrm{~d}^{-1}$ for 'very poorly drained soils'. The gross irrigation water requirements $I_{g r}\left(\mathrm{~mm} \mathrm{~d}^{-1}\right)$ (i.e., the amount of water that actually has to be extracted from external water resources) is computed by adjusting the net irrigation demand by the irrigation efficiency $E(-)$ that represents the water losses during irrigation water distribution and the application on the field scale. It is important to note that this efficiency relates to the classical concept of irrigation efficiency at the field scale, but not to the 'effective' irrigation efficiency that describes efficiency at larger scales and takes into account upstream losses as a source for irrigation water downstream (e.g., Molden et al., 2003; Perry, 1999).

A simple temperature threshold was applied to determine the start of the growing season in areas where crop growth is limited by temperature conditions; a threshold for the mean monthly air temperature of $5{ }^{\circ} \mathrm{C}$ was used. To determine the onset of the growing season in other regions, we assumed that the growing season starts one month before the month with the maximum rainfall in a given year. If multiple cropping is possible, the second season is assumed to start 150 days after the first one.

The estimated water demand $I_{g r}$ for irrigation can be met by combining water from three water sources (in order): (1) locally 
stored water (see Small reservoirs in $\mathrm{WBM}_{\text {plus }}$ below), (2) shallow groundwater (2.1.2), and (3) rivers flowing in the same grid cell. If the estimated per-grid cell water demand is higher than those sources combined, water is still applied, assuming that it is abstracted from non-renewable groundwater sources that are not connected to the local hydrological cycle, or from water transferred from adjacent gridcells (but not acounted for in the water budgeting of those gridcells).

\section{Water balance calculations in $W B M_{\text {plus }}$}

The soil water balance in the non-irrigated fraction of the grid cell can be described as

$$
d W_{s} / d t= \begin{cases}-g\left(W_{s}\right)\left(E T_{p}-P_{a}\right) & P_{a} \leq E T_{p} \\ P_{a}-E T_{p} & E T_{p}<P_{a} \leq D_{W S} \\ D_{W S}-E T_{p} & D_{w s}<P_{a}\end{cases}
$$

where $g\left(W_{s}\right)$ is a unitless soil moisture drying function, given by

$g\left(W_{s}\right)=\frac{1-e^{\left(-\alpha \frac{W_{s}}{W_{c}}\right)}}{1-e^{-\alpha}}$

and $W_{s}(\mathrm{~mm})$ is the soil moisture, $E T_{p}\left(\mathrm{~mm} \mathrm{~d}^{-1}\right)$ is the potential evapotranspiration, $P_{a}\left(\mathrm{~mm} \mathrm{~d}^{-1}\right)$ is the precipitation available for soil moisture recharge (rainfall $P_{r}$ plus snowmelt $M_{s}$ ), and $D_{w s}$ $(\mathrm{mm})$ is the soil moisture deficit to fill soil to its capacity and satisfy $E T_{p} . W_{c}(\mathrm{~mm})$ is the soil and vegetation-dependent available water capacity and $\alpha$ is an empirical constant (set to 5.0) (Vörösmarty et al., 1998).

Water in excess of the soil water holding capacity $X_{r}\left(\mathrm{~mm} \mathrm{~d}^{-1}\right)$ is partially $\left(\gamma X_{r}\right)$ released to the nearby river directly as surface runoff or diverted into the shallow groundwater pool $\left((1-\gamma) X_{r}\right)$ which is represented as a simple runoff retention pool that delays runoff before it enters the river channel and is described as

$\frac{d D_{r}}{d t}=(1-\gamma) X_{r}-\beta D_{r}$

The river runoff generated in this grid cell becomes

$R_{r}=\gamma X_{r}+\beta D_{r}$

where $D_{r}\left(\mathrm{~mm} \mathrm{~d}^{-1}\right)$ is the rainfall-runoff detention pool, $R_{r}(\mathrm{~mm}$ $\left.\mathrm{d}^{-1}\right)$ is the runoff from the grid cell, $\beta\left(\mathrm{d}^{-1}\right)$ is an empirical parameter that controls the outflow from the runoff pool and $\gamma(-)$ determines the fraction of excess rainfall that fills the pools or becomes runoff that same day. The parameter $\beta$ has been set to $0.0167 ; \gamma$ is set to 0.5 .

Horizontal transport in $\mathrm{WBM}_{\text {plus }}$ is only allowed through the gridded river network. In the current study, we used a Muskingum type solution that estimates discharge in a grid cell as a linear combination of discharge from upstream grid cells, the outflow at the previous time step and the runoff in the grid cell. Weighting coefficients for the Muskingum method are derived from empirical parameterizations of river bed geometry using power functions (Knighton, 1998).

\section{Small reservoirs in $W B M_{\text {plus }}$}

$\mathrm{WBM}_{\text {plus }}$ distinguishes between large reservoirs that alter the horizontal transport of water through the river network and small reservoirs that are located in grid cells with irrigation. Water release from large reservoirs is calculated as a function of reservoir capacity, inflow, and reservoir storage (Wisser et al., 2009) and can augment river flow during low-flow periods from which irrigation water can be abstracted.

Small reservoirs (SR's) in $\mathrm{WBM}_{\text {plus }}$ are assumed to collect part of the estimated surface runoff from the non-irrigated part of the grid cell and partially supply the estimated irrigation water requirement $I_{g r}$ in the irrigated fraction of the grid cell. We do not model the actual distribution of reservoirs within a grid cells but determine the total per-grid cell capacity of reservoirs by assuming that they have a uniform depth of $h=2 \mathrm{~m}$, a typical depth of small reservoir in the semi-arid regions of India (Gunnell and Krishnamurthy, 2003; Mialhe et al., 2008). We assumed volume of $1000 \mathrm{~m}^{3}$ for individual reservoirs ( $S R$ area $=500 \mathrm{~m}^{2}=0.05 \mathrm{ha}$ ) to estimate the number of reservoirs. Srivastava (2001) suggested a volume of $1750 \mathrm{~m}^{3} \mathrm{ha}^{-1}$ is necessary to irrigate two consecutive crops in India, and Senay and Verdin (2004) based their analysis on the potential of rainwater harvesting in Africa by assuming that the capacity of individual ponds is $1000 \mathrm{~m}^{3}$.

The amount of surface water that can actually be collected depends on a number of local conditions including soil texture, land use, and topography, as well as socio-economic factors (Kahinda et al., 2008; Qadir et al., 2007), and those criteria are mostly sitespecific (Rockström, 1999). In accord with how runoff harvesting systems are typically designed (Srivastava, 2001), we constrain the accumulated capacity of small reservoirs in each grid cell by the fraction of surface runoff that can be collected and the total amount of irrigation water needed in each grid cell in a typical year. The grid cell small reservoir storage capacity $C_{s r}$ is therefore determined by

$C_{S R}=\min \left(\sum \mu \gamma X_{r}, \Sigma I_{g r}\right)$

where $\mu$ is a coefficient that determines the fraction of surface runoff that is actually collected. The most appropriate design parameter to determine $\mu$ is the relationship between the catchment area for a reservoir at which runoff is collected and the cultivated area supplied by an individual reservoir. This parameter is commonly referred as the catchment command area ratio (CCR) (Critchley et al., 1991) and the design objective is to minimize CCR, as higher values lead to high evaporation and percolation losses that render small reservoirs less effective and economical. This ratio strongly depends on the seasonal variability of rainfall and storage capacities. Values for CCR between 1.0 and 5.0 are generally considered appropriate but values ranging between 17 and 30 with an average of 20 have been reported (Boers and Benasher, 1982).

Evaporation $\left(\mathrm{mm} \mathrm{d}^{-1}\right)$ from small reservoirs will depend on the actual type of reservoir used to store the water (closed tanks, open surface reservoirs, covered reservoirs, etc.) and is computed (Martinez Alvarez et al., 2008) as

$E_{p}=k_{p} E T_{0}$

where $k_{p}$ is an evaporation coefficient that has been set to 0.6 ( $\mathrm{Ar}$ nold and Stockle, 1991).

\section{Climate data sets}

Monthly atmospheric forcing data (mean air temperature and precipitation) for the period 1998-2002 has been obtained from the CRU TS 2.1 (Mitchell and Jones, 2005), which represents observed gridded climate data at a spatial resolution of $30 \mathrm{~min}$ and has been widely used for continental and global-scale hydrological modeling. Daily values of precipitation have been generated stochastically based on the number of wet days and the monthly precipitation totals (Geng et al., 1986).

\section{Agricultural data sets}

The spatial distribution of irrigated areas was taken from the University of Frankfurt/FAO Global Map of Irrigated Areas (Siebert et al., 2005). Cropping intensities (number of crops grown per year) and irrigation efficiency data was taken from country level statistics provided by AQUASTAT (2008). 
The distribution of crops around the globe was taken from the dataset developed by (Monfreda et al., 2008) that shows the distribution of 175 distinct crops across the world in or near the year 2000 at a spatial resolution of $5^{\prime}$. Crops were aggregated into 4 groups (perennial, vegetables, rice, others) and average crop coefficients, $k_{c}$, were taken from Allen et al. (1998). Grid cell crop areas were aggregated to 30 -min resolution.

Soil hydraulic properties that determine the soil water holding capacity in both irrigated and non-irrigated fractions within grid cells have been taken from the UNESCO/FAO soil map of the world (FAO/UNESCO, 2003).

\section{Model simulations}

Model simulations were performed for a 5-year period from 1998 to 2002. As the actual number and density of small reservoirs is unknown we determined the reservoir capacity in each grid cell for varying values of the catchment command ratio CCR. A CCR value of 0 was the baseline simulation with no implementation of small reservoirs.

The required total reservoir capacity for each CCR value for each grid cell was estimated by taking the largest value computed for $C_{s r}$ Eq. (5) for 1998-2002. This represents the least favorable hydrological conditions (high demand for irrigation water and low availability of surface runoff) in the 5-years; this is a typical design goal for agricultural systems in general and small reservoirs (Döll and Siebert, 2002; Srivastava, 1996, 2001).

\section{Results and discussion}

\section{Irrigation water demand and water sources for irrigation}

The simulated mean global irrigation water demand using the Global Map of Irrigated Areas (280 million ha) for the period 1998-2002 was $3250 \mathrm{~km}^{3} \mathrm{a}^{-1}$, consistent with previous estimates (Hanasaki et al., 2007; Siebert and Döll, 2007). Simulated mean surface runoff for the same period was $19,000 \mathrm{~km}^{3} \mathrm{a}^{-1}$, half of global runoff $\left(38,600 \mathrm{~km}^{3} \mathrm{a}^{-1}\right)$. The mean surface runoff that could potentially be collected, stored and applied to irrigated areas (i.e. the surface runoff in the non-irrigated part of all irrigated grid cells) was $9600 \mathrm{~km}^{3} \mathrm{a}^{-1}$.

If SR's are not considered (i.e., $C C R=0$ ), the abstraction of river flow contributed $\sim 10 \%\left(290 \mathrm{~km}^{3} \mathrm{a}^{-1}\right)$ towards meeting the irrigation water demand and the abstraction of groundwater was about $40 \%\left(1400 \mathrm{~km}^{3} \mathrm{a}^{-1}\right)$. Almost half of the total global irrigation water demand $\left(1600 \mathrm{~km}^{3} \mathrm{a}^{-1}\right)$ could not be met by local water sources or non-renewable groundwater sources. These estimates are generally consistent with earlier work by Vörösmarty et al. (2005) who used a geospatial analysis and estimated the amount of water used in irrigated areas not supplied from local runoff and groundwater to be up to 35\%. Recently, Rost et al. (2008) suggested that almost half of the current water used in irrigated areas was coming from non non-local and non-renewable resources.

The construction of small reservoirs and the use of locally harvested water for irrigation purposes does not significantly lower the amount of irrigation water that must come from non-local or non-renewable sources (Fig. 1). While the percentage of nonrenewable water use could decrease from $49 \%$ to $44 \%$, most of the increase in locally stored water is offset by a decrease in groundwater use, as most of the non-renewable water abstractions occur in dry regions where water resources are very limited and surface water runoff is not available for storage (Fig. 2).

The fraction of irrigated areas that could be supplied by locally stored runoff is highest in areas with a pronounced seasonal distribution of rainfall and high rainfall amounts. By continent, the larg-

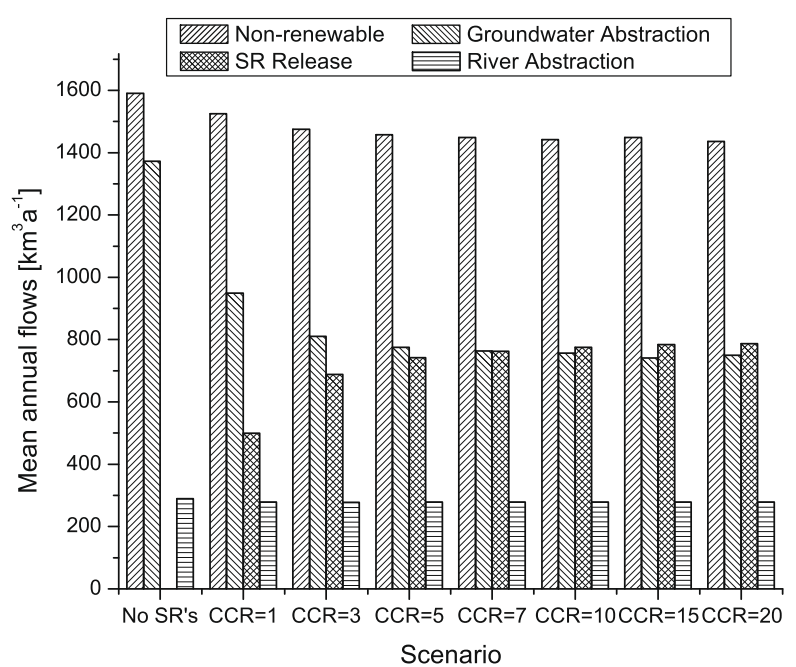

Fig. 1. $W_{B M}$ plus estimated sources for irrigation water demand under contemporary conditions (total demand $3250 \mathrm{~km}^{3} \mathrm{a}^{-1}$ ) for different scenarios of locally stored runoff.

est contribution of SR's to the estimated water demand in irrigated areas can be seen for South America, Europe, and North America. Assuming a CCR value of 5, the global contribution of locally stored runoff to irrigation water supply could be as high as $23 \%$ (Fig. 3) and is consistent, for example, with the estimated $37 \%$ of the total land under irrigation that is supplied by small reservoirs ('tanks') in the semi-arid regions of India (Anbumozhi et al., 2001).

The installed capacity for the $C C R=3$ scenario is $696 \mathrm{~km}^{3} \mathrm{a}^{-1}$ (for the one out of 5-year drought conditions) globally. Of the stored water, $688 \mathrm{~km}^{3} \mathrm{a}^{-1}$ is released for irrigation purposes on average, and $174 \mathrm{~km}^{3} \mathrm{a}^{-1}$ are lost through evaporation from the reservoir surface (Table 1 ). Note that SR release plus SR evaporation does not equal SR capacity (Table 1 ) because the capacity is set for the maximum demand while the release and evaporation values are the means of the 5-year simulations. Furthermore, the sum of reservoir release and reservoir evaporation can exceed reservoir capacity when the reservoir is filled multiple times.

The 'actual CCR' values in Table 1 are calculated as the area available in each grid cell divided by the irrigated area supplied from that collected runoff. Actual CCR is therefore constrained by the available area for runoff collection in the non-irrigated part of the grid cell, and the hydrological conditions (supply and demand), and can be less than the target maximum CCR value for a given scenario.

As the surface area-to-volume ratio in SR's is larger than for large, deep reservoirs, evaporation is much larger per unit of stored volume and represents $15-32 \%$ of the water released from SR's. The global surface area for SRs increases with CCR from $152,000 \mathrm{~km}^{2}$ $(\mathrm{CCR}=1)$ to $539,500 \mathrm{~km}^{2}(\mathrm{CCR}=20)$ (Table 1$)$. Evaporation losses also increase with CCR both in quantity and depth; the depth increase results from SRs in the higher CCR scenarios holding water for more of the year, while in low CCR scenarios the SRs only hold water for part of the year. The SR surface area is equivalent to 5.6$20 \%$ of the irrigated area $\left(2.7\right.$ million $\left.\mathrm{km}^{2}\right)$,

\section{Comparison with previous estimates}

Despite recent efforts to map the distribution of small reservoirs and the fluctuating water table using remotely-sensed data at the river basin scale (Liebe et al., 2005; Mialhe et al., 2008), small ponds are an uninventoried resource globally (Downing et al., 2006), and have previously been overlooked in large-scale assessments of water supply in irrigation. Downing et al. (2006) corre- 

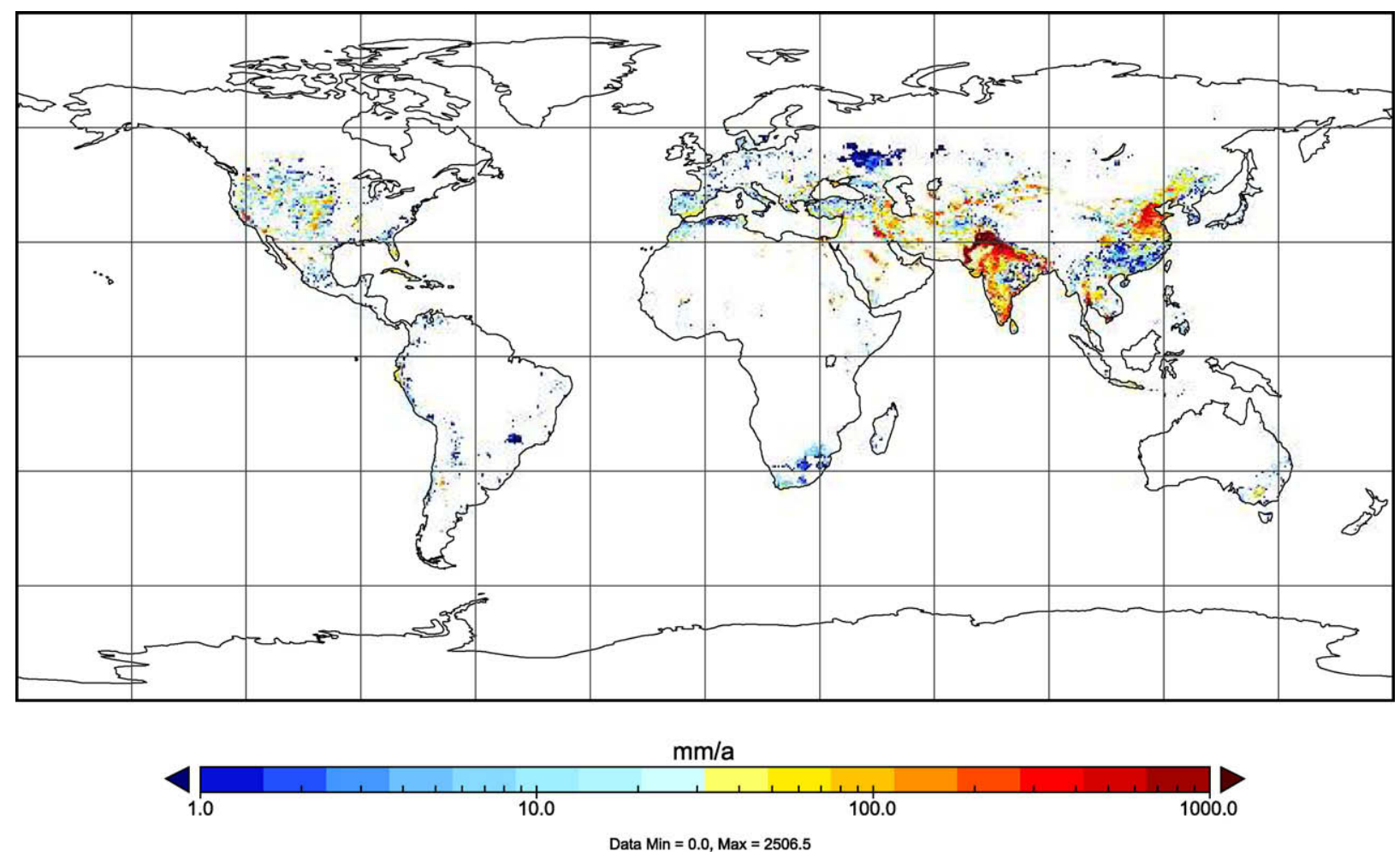

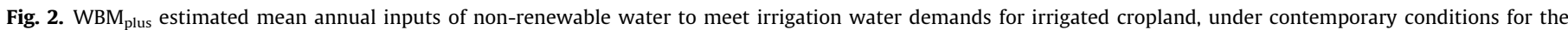
period $1998-2002$. Map is $0.5^{\circ}$ resolution.

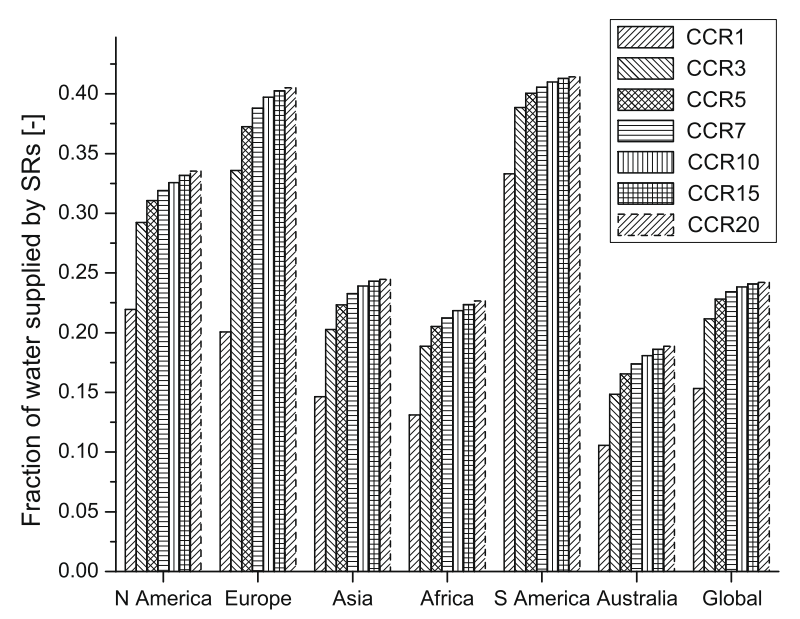

Fig. 3. Fraction of irrigated areas potentially supplied by locally stored water for different scenarios of reservoir capacity (CCR), by continent and globally. lated mean annual precipitation and the reported surface area of farm ponds for 13 political units (a province in India, several US states, Great Britain) and estimated the percentage of the area of farm land covered with small ponds using the relationship:

$F P=0.019 e^{0.0036 P}$

where $P\left(\mathrm{~mm} \mathrm{a}^{-1}\right)$ is the average annual precipitation and $F P$ is the pond area as a percentage of the farm area. Using this equation and assuming an average pond size of $0.001 \mathrm{~km}^{2}\left(1000 \mathrm{~m}^{2}\right.$ or $\left.0.1 \mathrm{ha}\right)$ they estimated the global surface area of ponds to be $78,773 \mathrm{~km}^{2}$, $22 \%$ of the CCR $=3$ SR area (Table 1 ). Assuming an average depth of $2 \mathrm{~m}$, the global estimated water volume in small ponds would be $154 \mathrm{~km}^{3}$, lower than our estimated capacity of $696 \mathrm{~km}^{3}$ for $\mathrm{CCR}=3$.

\section{Increased green water fluxes from cropland areas}

To calculate the potential contribution of SR's to global green water fluxes, we conducted a second set of simulations in which the SR's were located in all grid cells that contained cropland rather

Table 1

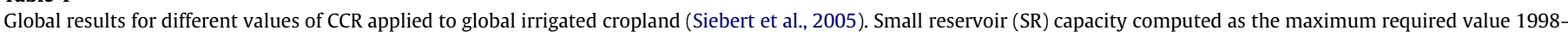

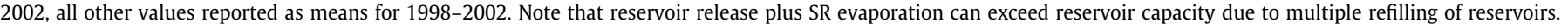

\begin{tabular}{|c|c|c|c|c|c|c|c|}
\hline \multirow[t]{2}{*}{ Max. CCR } & \multirow[t]{2}{*}{ Actual CCR } & \multirow[t]{2}{*}{ SR capacity $\left(\mathrm{km}^{3}\right)$} & \multirow[t]{2}{*}{ SR release $\left(\mathrm{km}^{3}\right)$} & \multirow[t]{2}{*}{ SR area $\left(\mathrm{km}^{2}\right)$} & \multicolumn{2}{|c|}{ SR evaporation } & \multirow[t]{2}{*}{ \# of SRs } \\
\hline & & & & & $\left(\mathrm{km}^{3} \mathrm{a}^{-1}\right)$ & $\left(\mathrm{mm} \mathrm{a}^{-1}\right)$ & \\
\hline 1 & 0.95 & 304 & 499 & 152,000 & 71 & 464 & $304,000,000$ \\
\hline 3 & 2.59 & 696 & 688 & 348,000 & 174 & 500 & $696,000,000$ \\
\hline 5 & 3.93 & 884 & 742 & 442,000 & 218 & 493 & $884,000,000$ \\
\hline 7 & 5.11 & 968 & 762 & 484,000 & 236 & 488 & $968,000,000$ \\
\hline 10 & 6.71 & 1022 & 775 & 511,000 & 246 & 481 & $1022,000,000$ \\
\hline 15 & 9.09 & 1062 & 784 & 531,000 & 252 & 474 & $1062,000,000$ \\
\hline 20 & 11.27 & 1079 & 787 & 539,500 & 254 & 471 & $1079,000,000$ \\
\hline
\end{tabular}


than restricting them to grid cells that contained only mapped irrigation (Siebert et al., 2005). In these simulations, we assumed that water can be collected from all non-cropland area within a grid cell. We used the global cropland data layers from Ramankutty et al. (2008), which represent cropland ca. 2000 and were derived by combining agricultural inventory data and satellite-derived land cover data. We calculated irrigation water needs as described above (Data and methods) under the assumption that all cropland can be irrigated if required, and irrigation water will be applied to avoid any crop-water stress. Cropland in regions with abundant, evenly-distributed precipitation require minimal to zero irrigation water. No SRs are placed in grid cells that contain no cropland.

The area that is available for runoff collection is around 7.2 billion ha, about five times the global cropland area ( 1.47 billion ha). As the area that is actually available for collection of surface runoff is unknown, we again computed SR-derived green water fluxes for different scenarios of CCR values, ranging from 1 to 20. The upper limit for CCR for each scenario is the area available for surface collection.

Gross irrigation water demand for all cropland areas was $11,920 \mathrm{~km}^{3} \mathrm{a}^{-1}$, a fourfold increase over the estimate for only those areas equipped for irrigation. If no locally stored runoff could be used to supply that amount of water it would have to be supplied by non-renewable water resources to a considerable degree $\left(6158 \mathrm{~km}^{3} \mathrm{a}^{-1}\right)$ and groundwater $\left(5202 \mathrm{~km}^{3} \mathrm{a}^{-1}\right)$ while only $559 \mathrm{~km}^{3} \mathrm{a}^{-1}$ could be supplied from local river discharge. The estimated green water flux from croplands under the assumption that SR-derived irrigation water is applied whenever crop water stress occurs averaged $6500 \mathrm{~km}^{3} \mathrm{a}^{-1}$ for the period 1998-2002. This estimate for the cropland area is consistent with previous estimates of the water consumption on croplands (Rockström et al., 1999; Rost et al., 2008). The estimated reservoir capacity (designed for the maximum demand during the 5-year period 1998-2002) ranges from $1538 \mathrm{~km}^{3}$ to $3566 \mathrm{~km}^{3}$ (Table 2), representing $21-50 \%$ of the estimated $7000 \mathrm{~km}^{3}$ capacity of large reservoirs with a dam height $\geqslant 15 \mathrm{~m}$ (Vörösmarty et al., 2003, 1997). The mean annual increase in green water flux due to the release of water from SR's, $\triangle E T$ (taking into account irrigation efficiencies) ranges from 623 to $1121 \mathrm{~km}^{3} \mathrm{a}^{-1}$ (Table 2), equivalent to $9.5-18 \%$ of the total green water flux from all cropland area. A considerable fraction of the water stored in SR's is lost to the atmosphere as evaporation from the surface. On average, a volume equivalent to $\sim 450 \mathrm{~mm}$ is lost from SR's, representing around 25\% of the installed reservoir capacity. On average, the release from SR's ranges from $1847 \mathrm{~km}^{3}$ $\mathrm{a}^{-1}$ to $2511 \mathrm{~km}^{3} \mathrm{a}^{-1}$. This estimate is much larger than the previously estimated volume of surface water available for storage in croplands in Africa, Asia, and South America alone of around 300 $\mathrm{km}^{3} \mathrm{a}^{-1}$ (Rockström et al., 1999).

\section{Implications for food production}

In general, crop yields increase with higher crop evapotranspiration up to a certain limit, and low-yields can partially be ex- plained due to a lack of adequate water supply; other factors influencing crop yield include soil fertility and nutrient supply, pests, severe weather events, and low-yielding crop varieties (Zwart and Bastiaanssen, 2004). Crop productivity in some rainfed areas can significantly be improved with supplemental irrigation during critical crop growth stages (Oweis and Hachum, 2006). Increases in green water flux supplied by local storage of surface runoff in small reservoirs could potentially enhance crop growth and productivity, and thereby have implications for food security.

To assess this potential, we spatially related the estimated SRderived increases in green water fluxes to actual crop production. To compute the mean area-weighted actual yield in each grid cell, we used crop yield data sets compiled by Monfreda et al. (2008), which spatially represent the area and yield of 175 crops globally. To avoid biases in computing an area-weighted grid cell yield arising from large yield differences for individual crops, we computed the relative yield for crop $i$ in grid cell $c$ for each of the 11 crop groups (cereals, fibers, forage, fruits, oilcrops, pulses, roots, sugarcrops, treenuts, vegetables, and others) as

$Y_{i, c}^{*}=\frac{Y_{i, c}}{Y_{i, \max }}$

where $Y_{i, \max }$ is the reported global maximum yield ( $\mathrm{t} \mathrm{ha} \mathrm{a}^{-1}$ ) for crop $i$. The area-weighted relative yield in each grid cell $c$ is then calculated as

$\bar{Y}_{c}=\frac{\sum_{i} Y_{i, c}^{*} A_{i, c}}{\sum_{i} A_{i, c}}$

where $A_{i, c}$ is the area for crop $i$ in grid cell $c$, both taken from Monfreda et al. (2008). Globally, the average area-weighted yield for all crops, $\bar{Y}$ is $6.7 \mathrm{tha}^{-1}$ (median $=5.4 \mathrm{tha}^{-1}$ ) and shows a considerable range of values in different regions of the world. We normalized the relative yield as $\overline{Y_{c}^{*}}=\left(\overline{Y_{c}}-\bar{Y}\right) / \bar{Y}$. The resulting spatial distribution of crop yields is shown in Fig. 4. Above average normalized yields (positive numbers) can be found North America, Europe, and Oceania.

The greatest potential for improving yield values is in Africa, where better water and fertilizer input could increase production (Liu et al., 2008). Generally, all cropland areas show a potential for annual increases in green water fluxes due to implementation of global cropland SRs, with the highest values for increasing green water flux found in the areas with a pronounced seasonal distribution of rainfall of considerable rainfall depth, such as East Asia, Western Africa, and parts of Australia (Fig. 5).

Fig. 6 shows the distribution of estimated increases in green water flux and actual yield on a grid cell basis globally and for individual continents. Regions with the highest potential for increases in yield as a result of increases in green water fluxes are generally areas with below-average yield and considerable additional green water flows. By continent, much of those regions are found in Africa and Asia whereas the potential for yield increases in Europe and North America is low.

Table 2

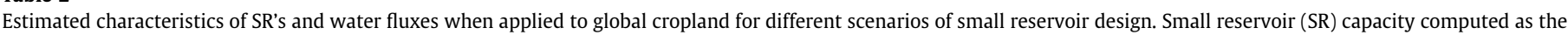
maximum required value 1998-2002, all other values reported as means for 1998-2002.

\begin{tabular}{|c|c|c|c|c|c|c|c|}
\hline \multirow[t]{2}{*}{ Max. CCR } & \multirow[t]{2}{*}{ Actual CCR } & \multirow[t]{2}{*}{ SR Capacity $\left(\mathrm{km}^{3}\right)$} & \multirow[t]{2}{*}{ SR Release $\left(\mathrm{km}^{3} \mathrm{a}^{-1}\right)$} & \multirow[t]{2}{*}{ SR Area $\left(\mathrm{km}^{2}\right)$} & \multicolumn{2}{|c|}{ SR Evaporation } & \multirow[t]{2}{*}{$\Delta \mathrm{ET}\left(\mathrm{km}^{3} \mathrm{a}^{-1}\right)$} \\
\hline & & & & & $\left(\mathrm{km}^{3} \mathrm{a}^{-1}\right)$ & $\left(\mathrm{mm} \mathrm{a}^{-1}\right)$ & \\
\hline 1 & 1.0 & 1538 & 1847 & 769,132 & 390 & 507 & 623 \\
\hline 3 & 2.5 & 2790 & 2336 & 1395,119 & 699 & 501 & 966 \\
\hline 5 & 3.7 & 3192 & 2432 & 1596,108 & 778 & 487 & 1054 \\
\hline 7 & 4.8 & 3356 & 2465 & 1677,978 & 804 & 479 & 1083 \\
\hline 10 & 6.3 & 3462 & 2488 & 1731,135 & 819 & 473 & 1103 \\
\hline 15 & 8.5 & 3535 & 2504 & 1767,327 & 829 & 469 & 1116 \\
\hline 20 & 10.4 & 3566 & 2511 & 1782,758 & 832 & 467 & 1121 \\
\hline
\end{tabular}



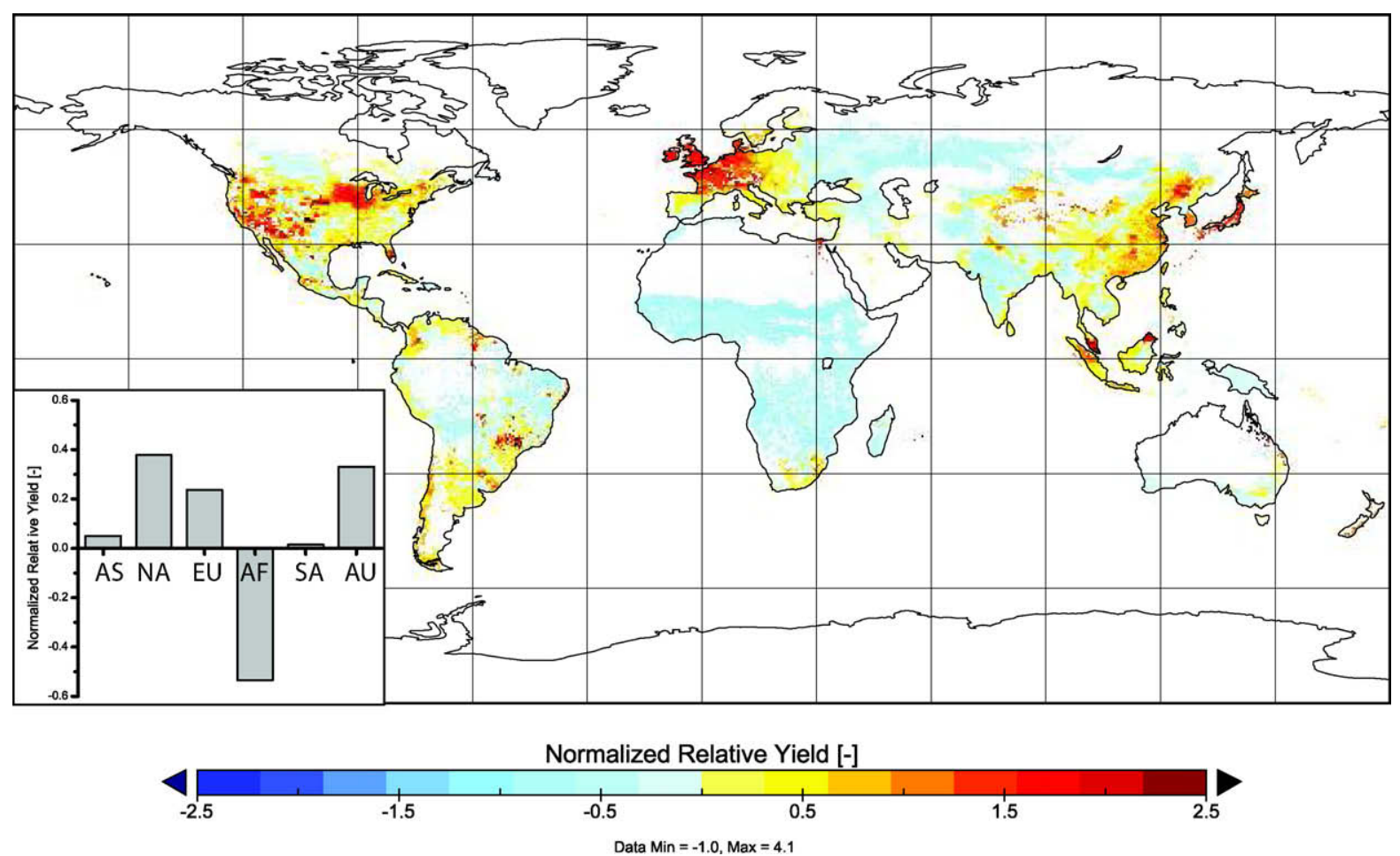

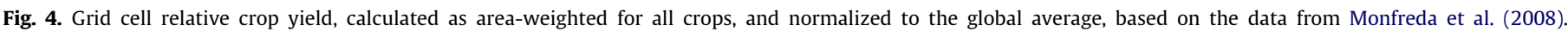
Inset:average relative yield per continent. Global mean yield of $6.7 \mathrm{t} \mathrm{ha}^{-1}$ is 0.0 in this plot. See Eqs. (8) and (9) in text for methods.
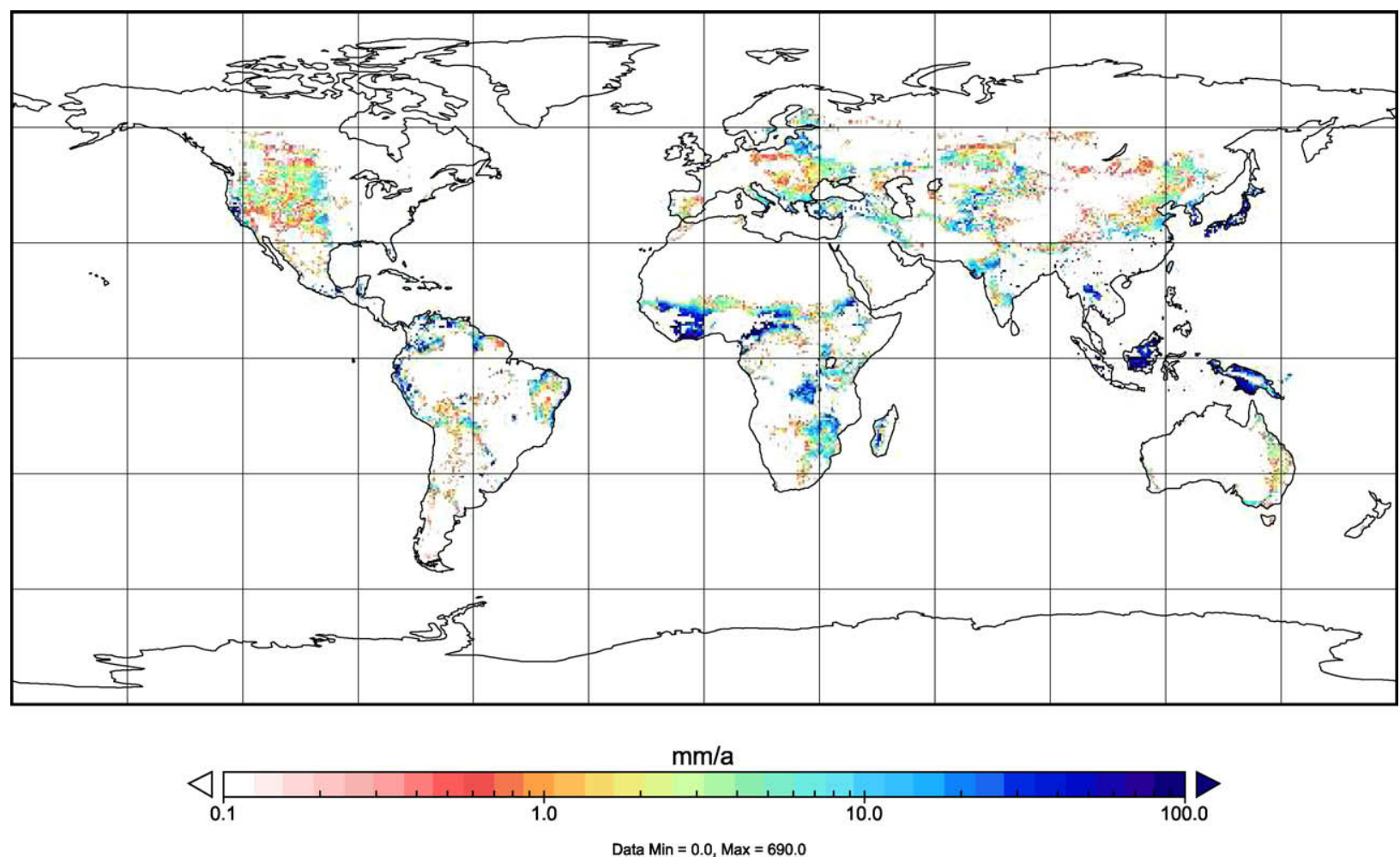

Fig. 5. Mean annual (1998-2002) additional evapotranspiration (green water) fluxes in cropland areas supplied by water released from small reservoirs for CCR = 5.

To put the estimated increases in green water fluxes in a foodproduction perspective, we made a simple estimate of how the increases in cropland green water fluxes could translate to increases in food production. A key concept in relating crop yield to crop evapotranspiration is the crop water productivity (CWP), sometimes referred to as water use efficiency (WUE) which is defined as the ratio between yield and actual evapotranspiration (Zwart and Bastiaanssen, 2004): 

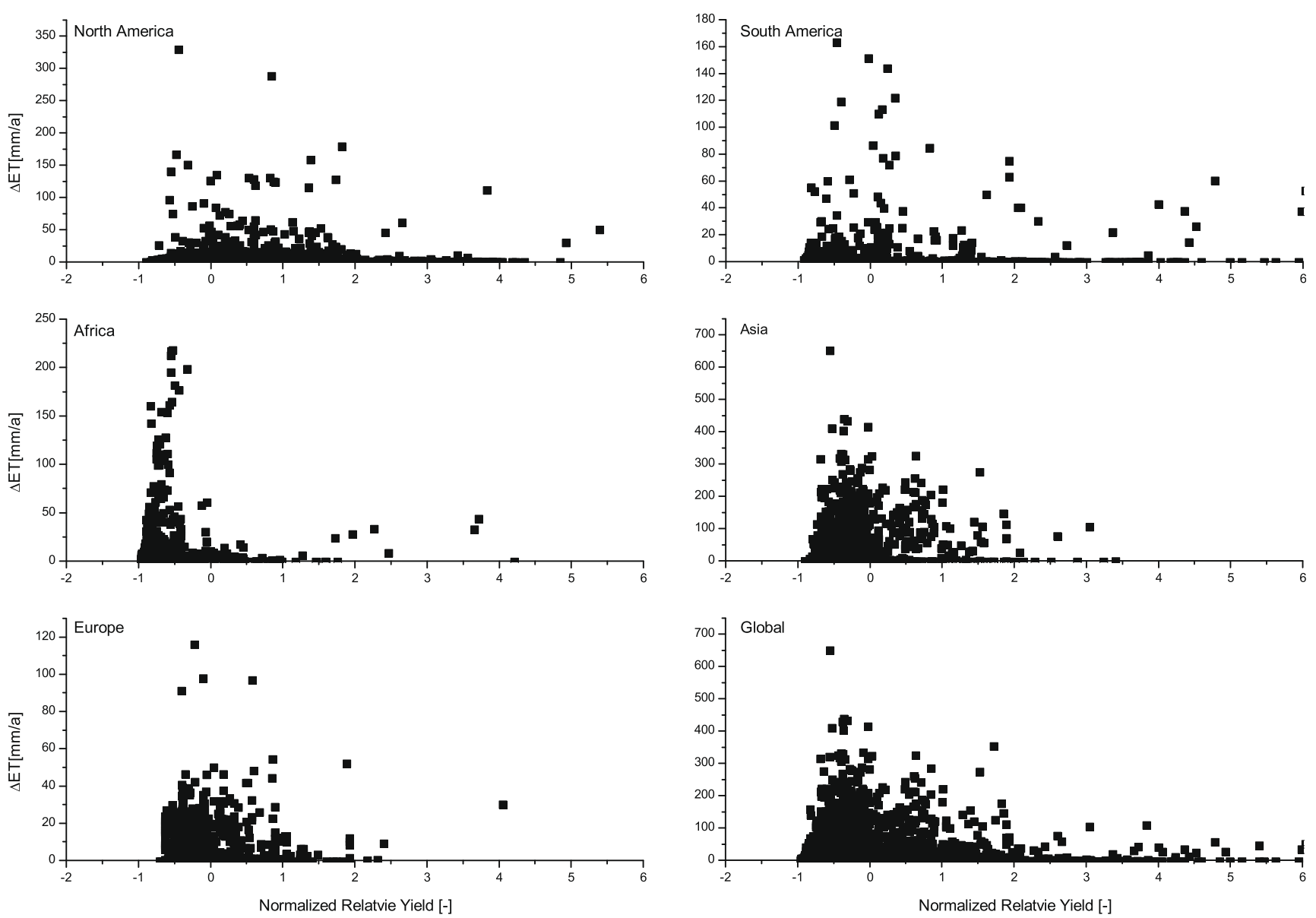

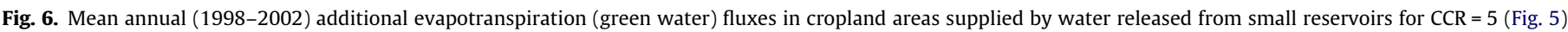

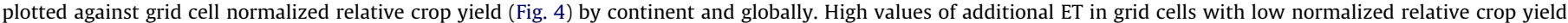
indicate a high potential for increased food production through use of small reservoirs (e.g., Africa and Asia).

$$
C W P=\frac{Y}{E T}
$$

where $Y\left(\mathrm{~kg} \mathrm{ha}^{-1}\right)$ is the yield, ET is the actual crop evapotranspiration $\left(\mathrm{m}^{3} \mathrm{ha}^{-1}\right)$ and CWP is the crop water productivity $\left(\mathrm{kg} \mathrm{m}^{-3}\right)$. CWP depends on a number of factors including available water supply, field and local cultural and management practices, crop breed, fertilizer input and others that are difficult to assess for global-scale applications (Rockström et al., 1999; Zwart and Bastiaanssen, 2004). Based on 84 literature sources, Zwart and Bastiaanssen (2004) have compiled reported values for CWP for wheat, cotton, and maize and found a wide range of values depending on climate, water management, soil management conditions and others. The mean values of CWP for both rice and wheat were $1.09 \mathrm{~kg} \mathrm{~m}^{-3}$, and $1.80 \mathrm{~kg} \mathrm{~m}^{-3}$ for maize. A nominal CWP of $1.0 \mathrm{~kg} \mathrm{~m}^{-3}$ was used in assessments of virtual water trade between countries (Yang et al., 2006); we adopted this constant value for our analysis.

Potential gains in crop production were estimated by multiplying CWP by the additional productive (i.e., accounting for percolation and evaporation losses) green water flux from local water storage in SR's as

$$
\Delta Y=\Delta E T \cdot C W P
$$

where $\Delta E T\left(\mathrm{~m}^{3} \mathrm{ha}^{-1}\right)$ is the difference in estimated crop evapotranspiration that can be attributed to the water released from small reservoirs. Table 3 shows the potential increase in cereal crop production by continent and globally, and assuming the linear relationship Eq. (11) between yield and CWP for all increases in ET, and
Table 3

Potential increases in cereal production $\left(\mathrm{Mt} \mathrm{a}^{-1}\right)$ due to increased green water fluxes from cropland areas by continents for different scenarios of small reservoir design (CCR), assuming a crop water productivity of $1.0 \mathrm{~kg}$ yield $\mathrm{m}^{-3}$ water.

\begin{tabular}{lccccc}
\hline & CCR $=1$ & CCR $=5$ & CCR $=10$ & CCR $=15$ & CCR $=20$ \\
\hline Africa & 72 & 176 & 194 & 202 & 205 \\
Europe & 19 & 41 & 44 & 44 & 44 \\
South America & 45 & 89 & 95 & 96 & 96 \\
North America & 46 & 80 & 82 & 83 & 83 \\
Australia & 11 & 17 & 18 & 18 & 18 \\
Asia & 429 & 650 & 670 & 674 & 674 \\
Global & 623 & 1054 & 1103 & 1116 & 1122
\end{tabular}

that no other factors were limiting yield (an idealized assumption). In some respects, this estimate can be viewed as representing an absolute upper limit to the expected increase in food production, as yield cannot be improved above certain limits when it is already high, and many other factors can also limit crop yields. However, because additional water could prevent crop failure (i.e., a highly non-linear relationship between additional water and increased yield), this estimate could be low in some circumstances. Compared to current cereal production, the potential increase for an installed reservoir capacity for CCR $=5$ represents an increase of $\sim 50 \%$, much of the potential being in Africa and Asia (Table 3).

As discussed above, yield is more likely to increase with CWP for lower ranges of yield values. We therefore restricted the analysis of potential increases in food production due to increased green 
water fluxes to areas with a current yield below the average of 6.7 t/ha (i.e., less than zero in Fig. 4), assuming that the lower yield is at least partially related to inadequate soil water management due to the lack of irrigation. The estimated potential crop yield increase (Table 4$)$ ranges from $20 \%(C C R=1)$ to $38 \%(C C R=20)$ of the global production of $\sim 2$ billion tonnes of cereals (FAOSTAT, 2008; Monfreda et al., 2008). Most of the increase is projected for Africa and Asia whereas only small increases could be expected in Europe and North America (as yields are generally already above average). These projected increases in crop production by supplemental irrigation are in general agreement with observed yield increases at the farm level (e.g., Oweis and Hachum, 2006).

The largest relative increase in food production is seen in Africa where cereal yields are around $1 \mathrm{t} \mathrm{ha}^{-1}$ and food production is doubled for medium variants of SR construction. The low-yields in many regions in Africa, the Sahel regions in particular are generally a result of limited water availability (Rockström, 1999). Although the rapid expansion of global irrigated areas has recently slowed down, there is still a potential for the expansion of irrigated areas, particularly in Sub-Saharan Africa, where only about 5\% of the total cropland is currently under irrigation (Rockström et al., 2007) and existing cropland areas could be upgraded to irrigated areas by locally stored runoff.

To further put the estimated increases in food production into perspective, we compared the estimated increases with the global cereal food aid for the period 2003-2005, reported as equivalent to 7.7 million tonnes per year (FAOSTAT, 2008) or $0.4 \%$ of the global cereal production For installed reservoir capacities with catchment areas equal to the supplied area $(C C R=1)$, the cereal food aid for Africa and Asia represents only $5 \%$ and $1 \%$, respectively, of the potential (ideal) increase in cereal production with SR-derived water (Table 4 and Fig. 7). It is important to note, however, that some of this potential for supplementary irrigation at small, farm-scale, individually-managed systems is already implemented, but not included in either global inventories of irrigated areas or reservoir databases. Global datasets based on national censuses data tend to underestimate the small-scale irrigation that is known to play an important role in, for example, some African countries (Siebert and Döll, 2007).

\section{Downstream effects of SR'S}

Small reservoirs not only constitute a fundamental human transformation of the landscape (Smith et al., 2002); they can also significantly alter the hydrological regime and the distribution of water and sediments at the local level through alterations in evaporation, percolation, and groundwater recharge. The effects of increased water productivity at the river basin level are therefore a downstream concern (Ngigi, 2003). To assess the impact of additional water storage in SR's on the water available downstream we compared discharge at the outlet in all river basins based on the STN-30 river network (Vörösmarty et al., 2000a,b) simulated

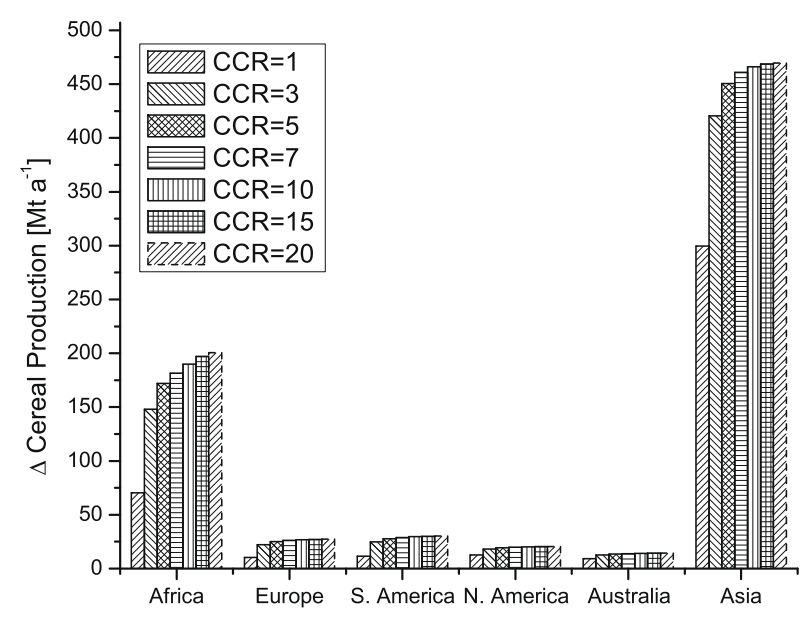

Fig. 7. Potential increases in cereal production due to increased green water fluxes from cropland areas by continents for different scenarios of reservoir sizes for areas with average relative crop yield below the global average.

under contemporary conditions and with the maximum SR volume $(\mathrm{CCR}=20)$.

Globally, the average volume of water 'lost' to evapotranspiration from SR's (release from reservoir plus evaporation from the reservoir surface) annually for the period 1998-2002, assuming $\mathrm{CCR}=20$ is $\sim 3000 \mathrm{~km}^{3}$ (Table 2), representing $\sim 8 \%$ of the longterm mean terrestrial discharge $\left(\sim 38,500 \mathrm{~km}^{3}\right)$. Out of the 6159 river basins that are delineated in the STN-30 river network, the discharge at the basin mouth of 2963 river basins ( $\sim 40 \%$ of all river basins globally) will be affected by changing hydrological conditions due to the collection and storage of surface runoff upstream. The aggregate reduction in annual flow for those river basins is $18 \%$. The relative reduction in mean annual flow is highest in smaller basins, where it can reach up to $80 \%$. However, macroscale hydrological models are less reliable predictors of the dynamics of small basins - Vörösmarty et al. (2000b) recommended a minimum basin size for analysis of $\sim 25,000 \mathrm{~km}^{2}$, equivalent to about 10 half-degree grid cells. Globally, there are 416 of these 'large' river basins that contain cropland. Mean SR impacts on flows in these large basins are a $2 \%$ reduction in maximum monthly flow (range $0-15 \%$ ), a $5 \%$ reduction in mean annual flow (range $0-33 \%$ ), and a $44 \%$ reduction in minimum monthly flow that ranges from zero to $100 \%$ (i.e. a complete drying up of the minimum flow) compared to flow under baseline conditions (Fig. 8).

\section{Uncertainties}

We recognize that our results are sensitive to number of uncertainties arising from a set of simplified assumptions with regard to the estimated reservoirs capacity, as well as to uncertainties in the

\section{Table 4}

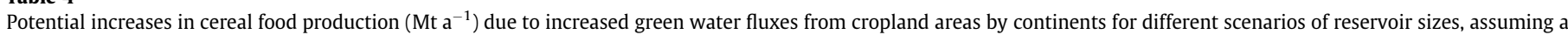

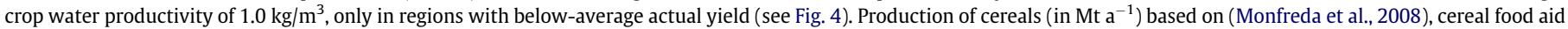
imports from (FAOSTAT, 2008).

\begin{tabular}{|c|c|c|c|c|c|c|c|}
\hline & $\mathrm{CCR}=1$ & $\mathrm{CCR}=5$ & $\mathrm{CCR}=10$ & $\mathrm{CCR}=15$ & $\mathrm{CCR}=20$ & Production 2000 & Food aid $2005 / 2007$ \\
\hline Africa & 70 & 172 & 190 & 197 & 201 & 99 & 4.1 \\
\hline Europe & 10 & 25 & 27 & 27 & 27 & 358 & 0.0 \\
\hline South America & 12 & 28 & 30 & 30 & 30 & 101 & 0.4 \\
\hline North America & 13 & 19 & 20 & 20 & 21 & 421 & 0.0 \\
\hline Australia & 9 & 14 & 14 & 14 & 14 & 33 & 0.0 \\
\hline Asia & 300 & 451 & 466 & 469 & 470 & 990 & 3.2 \\
\hline Global & 414 & 709 & 747 & 758 & 763 & 2002 & 7.7 \\
\hline
\end{tabular}




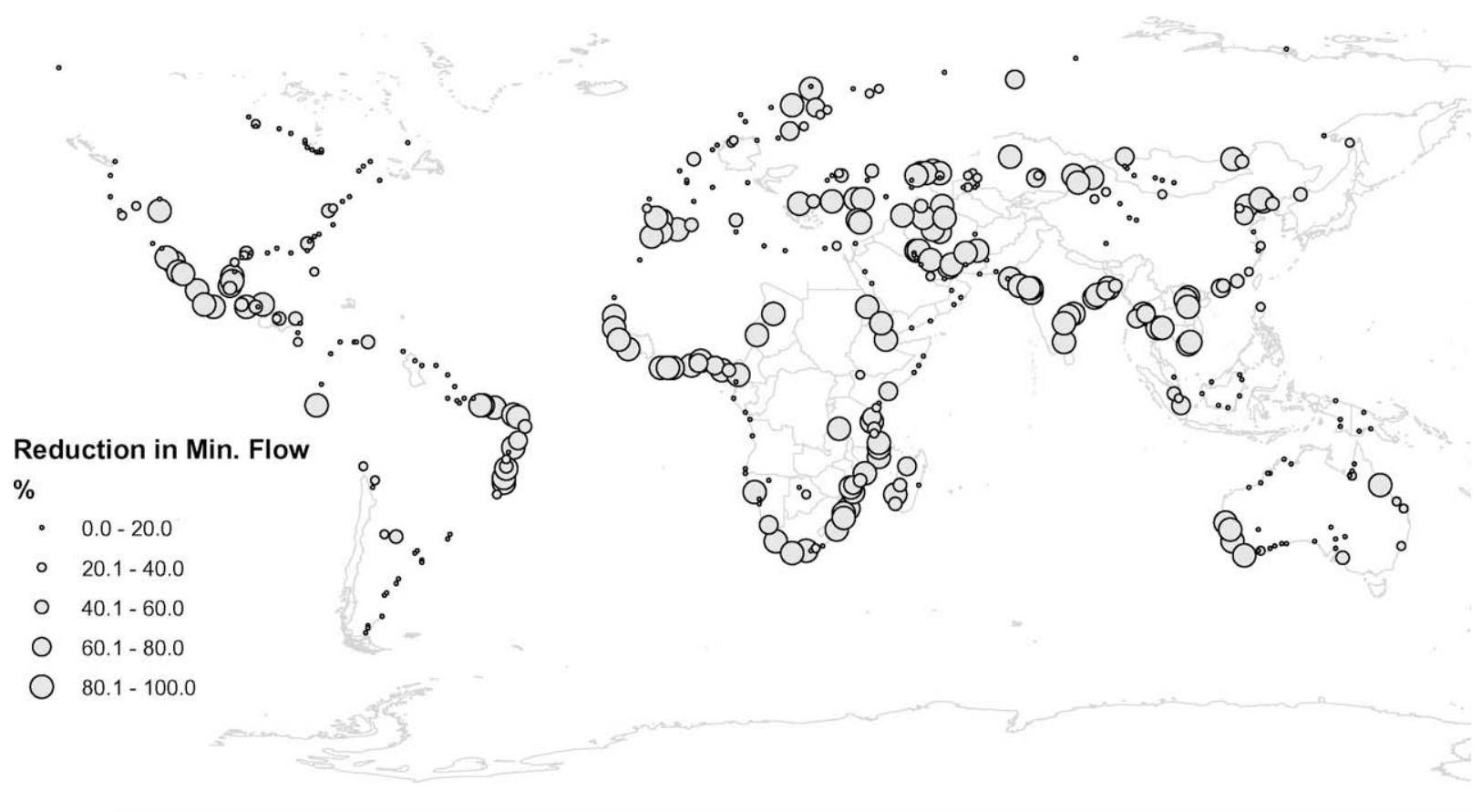

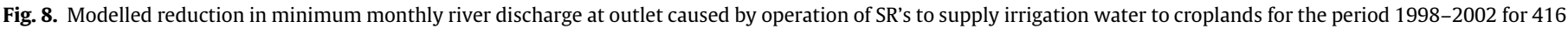
river basins $\left(A>25,000 \mathrm{~km}^{2}\right)$ with cropland area.

input data related to the agricultural data sets. The results presented here should be viewed as a first estimate of the global geography of the potential of small reservoirs. The actual potential at the implementation level (small reservoirs are a local strategy) depends on a number of local conditions that are not known at the scale of our analysis and must be determined using site-specific rainfall-runoff relationships.

For example, the assumption that the surface runoff can always be collected depends on the local topographic conditions, geology, land use and a number of small-scale characteristics such as the spatial and temporal variability in rainfall, not included in our model. Our simplified approach may lead to an overestimation of the small reservoir potential (Frot et al., 2008). On the other hand, the assumption of a constant crop water productivity of $1.0 \mathrm{~kg} \mathrm{~m}^{-3}$ and a linear increase in yield with increasing evapotranspiration may be too conservative as supplemental irrigation can avoid crop failures and thereby lead to a much higher increase in crop water productivity (Rockström et al., 2002, 2007). Furthermore, the assumption of a linear relationship between yield and CWP may not be valid for lower ranges of yield (Rockström et al., 2007).

We did not consider the loss of reservoir storage over time due to siltation, which can be significant in some regions depending on local geology, soil type, rainfall distribution, and vegetation. This can lead to a partial or complete loss of reservoir capacity, and is a significant problem for small ponds (Gunnell and Krishnamurthy, 2003). It can be addressed by periodic desilting.

Considerable uncertainties with regard to the estimated water withdrawal for irrigated agriculture have been shown to be associated with agricultural and climate data sets (Wisser et al., 2008) that could lead to variations in estimated demand for agriculture of $\sim 30 \%$ globally depending on different combinations of agricultural data sets and weather data.

The implementation and adoption of rainwater harvesting technologies is also constrained by a number of socio-economic factors that need to be considered when planning, constructing, and operating rainwater harvesting technologies (Oweis and Hachum, 2006). Such limitations include land ownership and use issues, water rights, downstream/upstream water requirements and cap- ital and labor resources that are best addressed on a watershed level.

\section{Conclusions}

We have presented a first global-scale assessment of small reservoirs, and their potential role in supplying locally stored water for irrigation water purposes. Using a water balance modeling approach, we estimated the potential distribution of small reservoirs to supply water in irrigated areas, and analyzed the contributions of surface water, shallow groundwater, local river water, and water from non-renewable sources to meet irrigation water demand. Globally, the construction of small reservoirs has a small influence on the fraction of irrigation water demand that must be supplied by non-renewable water resources. We estimate that about one third of the volume currently supplied to contemporary irrigated areas is supplied by water from locally stored runoff (i.e., small reservoirs or shallow groundwater).

The high area-to-volume ratio in SR's, relative to large reservoirs, results in high evaporation losses and generally decreases the overall efficiency of the system. We found an average of $20 \%$ of the water stored in small reservoir is evaporated from the reservoir surface, so in some situations it would be worthwhile to consider additional water saving measures for SR's, such as floating covers, windbreaks, or underground storage (Martinez Alvarez et al., 2008).

We evaluated the potential contribution of locally stored runoff to increase transpiration (green) water fluxes for all existing cropland areas, and the implications of such shifts for food production at large-scales. Based on simple assumptions regarding crop water productivity, we estimated that the global cereal production in low-yield regions could be increased by $\sim 35 \%$ for a medium variant of small reservoir construction (i.e., $C C R=5$ ). The projected increases as a result of increased green water fluxes are not uniformly distributed. The largest potential for upgrading existing cropland areas to irrigated areas by using locally stored runoff can be found in low-yield regions in Africa and Asia. Assuming that 
yield is only limited by available water, the construction of SR's could almost double the production of cereals in Africa and increase production in Asia by about 30\% for the minimum small reservoir capacity scenario $(\mathrm{CCR}=1)$.

As the construction of SRs alters the hydrological regime, downstream implications are a concern. We analyzed the reduction in annual river flow for a large variant of reservoir construction and found that mean annual flow in affected river basins is reduced by $18 \%$ on average. Impacts are likely to be most significant during low-flow seasons. These effects tend to be higher in small basins that are smaller than the minimum size that is adequately represented in a macroscale hydrological model with the resolution used here.

While the construction of small reservoirs has been shown to be an economically viable option for providing supplemental irrigation at the farm level (e.g., Panigrahi et al., 2005), our analysis highlights continental and global challenges and opportunities for runoff harvesting and the implications of increasing food production. In summary, we find that SR's can potentially significantly increase green water flow and thereby increase food production in areas where current crop yield is severely limited by available water. Being a technology that does not require large infrastructure investments, and that can be implemented at the level of individual farms, SR's are an important tool to improve food security in poor, drought-prone environments.

\section{Acknowledgments}

We acknowledge support from NASA's Terrestrial Hydrology Program (Grant NNX07AW08G), the NASA IDS Program (NNX07AH32G), and the NASA Applied Earth Sciences Program through Cooperative Agreement NNA06CN09A. We thank one anonymous reviewer and Holger Hoff for constructive comments on an earlier draft.

\section{References}

Allen, R.G., Pereira, L.S., Raes, D., Smith, M., 1998. Crop evapotranspiration: guidelines for computing crop water requirements, Food and Agricultural Organization of the United Nations (FAO).

Anbumozhi, V., Matsumoto, K., Yamaji, E., 2001. Towards improved performance of irrigation tanks in semi-arid regions of India: modernization opportunities and challenges. Irrigation and Drainage 15, 293-309.

AQUASTAT, 2008. FAOs global information system of water and agriculture. <http:// www.fao.org/ag/agl/aglw/aquastat/dbase/index.stm>.

Arnold, J.G., Stockle, C.O., 1991. Simulation of supplemental irrigation from on-farm ponds. Journal of Irrigation and Drainage Engineering 117, 408-424.

Boers, T.M., Benasher, J., 1982. A review of rainwater harvesting. Agricultural Water Management 5 (2), 145-158.

Bruins, H.J., Evenari, M., Nessler, U., 1986. Rainwater-harvesting agriculture for food production in arid zones: the challenge of the African famine. Applied Geography 6, 13-32.

Critchley, W., Siebert, K., Chapman, C., 1991. Water harvesting. A manual for the design and construction of water harvesting schemes, FAO, Rome.

Döll, P., Siebert, S., 2002. Global modelling of irrigation water requirements. Water Resources Research 38 (4), 8.2-8.10.

Downing, J.A. et al., 2006. The global abundance and size distribution of lakes, ponds, and impoundments. Limnology and Oceananography 51,5 .

FAO/UNESCO, 2003. Digital Soil Map of the World and Derived Soil Properties Version 3.6. CD ROM.

FAOSTAT, 2008. Statistical Database of FAO. <http://www.faostat.fao.org/>.

Fraiture, C.D., Wichelns, D., Rockström, J., Benedict, E.K., 2007. Looking ahead to 2050: scenarios of alternative investment approaches. In: Molden, D. (Ed.), Water for Food - Water for Life. A Comprehensive Assessment of water Management in Agriculture. Earthscan, pp. 91-145.

Frot, E., van Wesemael, B., Benet, A.S., House, M.A., 2008. Water harvesting potential in function of hillslope characteristics: a case study from the Sierra de Gador (Almeria province, south-east Spain). Journal of Arid Environments 72 (7), 1213-1231.

Geng, S., de Fries, F.W.T.P., Supit, I., 1986. A simple method for generating daily rainfall data. Agricultural and Forest Meteorology 36, 363-376.

Gunnell, Y., Krishnamurthy, A., 2003. Past and present status of runoff harvesting systems in dryland peninsular India: a critical review. Ambio 32 (4), 320-324.
Hanasaki, N., Kanae, S., Oki, T., Shirakawa, N., 2007. An integrated model for the assessment of global water resources: Part 2: Anthropogenic activities modules and assessment. Hydrology and Earth System Sciences 4, 3583-3626.

Jayatilaka, C.J., Sakthivadivel, R., Shinogi, Y., Makin, I.W., Witharana, P., 2003. A simple water balance modelling approach for determing water availability in an irrigation tank cascade system. Journal of Hydrology 273, 81-102.

Kahinda, J.M., Lillie, E.S.B., Taigbenu, A.E., Taute, M., Boroto, R.J., 2008. Developing suitability maps for rainwater harvesting in South Africa. Physics and Chemistry of the Earth 33 (8-13), 788-799.

Knighton, D., 1998. Fluvial Forms and Processes: a New Perspective. John Wiley \& Sons.

Li, Q., Gowing, J., 2005. A daily water balance model approach for simulating performance of tank-based irrigation systems. Water Resources Management $19,211-231$.

Li, F.R., Cook, S., Geballe, G.T., Burch, W.R., 2000. Rainwater harvesting agriculture: an integrated system for water management on rainfed land in China's semiarid areas. Ambio 29 (8), 477-483.

Liebe, J., van de Giesen, N., Andreini, M., 2005. Estimation of small reservoir storage capacities in a semi-arid environment - a case study in the Upper East Region of Ghana. Physics and Chemistry of the Earth 30 (6-7), 448-454.

Liu, J., Zehnder, A.J.B., Yang, H., 2008. Drops for Crops: modelling Crop Water Productivity on a Global Scale. Global Nest Journal 10 (3), 295-300.

Martinez Alvarez, V., Gonzalez-Real, M.M., Baille, A., Maestre Valero, J.F., Gallego Elvira, B., 2008. Regional assessment of evaporation from agricultural irrigation reservoirs in a semiarid climate. Agricultural Water Management 95 (9), 10561066.

Mbilinyi, B.P., Tumbo, S.D., Mahoo, H.F., Mkiramwinyi, F.O., 2007. GIS-based decision support system for identifying potential sites for rainwater harvesting. Physics and Chemistry of the Earth 32 (15-18), 1074-1081.

Mialhe, F., Gunnell, Y., Mering, C., 2008. Synoptic assessment of water resource variability in reservoirs by remote sensing: general approach and application to the runoff harvesting systems of South India. Water Resources Research 44, W05411.

Mitchell, T.D., Jones, P.D., 2005. An improved method of constructing a database of monthly climate observations and associated high-resolution grids. International Journal of Climatology 25 (6), 693-712.

Molden, D., Murray-Rust, H., Sakthivadivel, R., Makin, I., 2003. A Water-Productivity Framework for Understanding and Action. In: Kijne, J.W., Barker, R., Molden, D. (Eds.), Water Productivity in Agriculture:Limits and Opportunities for Improvement. Comprehensive assessment of water management in agriculure series. International Water Management Institute.

Monfreda, C., Ramankutty, N., Foley, J.A., 2008. Farming the planet: 2. Geographic distribution of crop areas, yields, physiological types, and net primary production in the year 2000. Global Biogeochemical Cycles 22, GB1022.

Ngigi, S.N., 2003. What is the limit of up-scaling rainwater harvesting in a river basin? Physics and Chemistry of the Earth 28 (20-27), 943-956.

Ngigi, S.N., Savenije, H.H.G., Rockstrom, J., Gachene, C.K., 2005. Hydro-economic evaluation of rainwater harvesting and management technologies: farmers' investment options and risks in semi-arid Laikipia district of Kenya. Physics and Chemistry of the Earth 30 (11-16), 772-782.

Oweis, T., Hachum, A., 2006. Water harvesting and supplemental irrigation for improved water productivity of dry farming systems in West Asia and North Africa. Agricultural Water Management 80 (1-3), 57-73.

Oweis, T., Hachum, A., Bruggeman, A., 2004. The role of indigenou knowledge in improving present water-harvesting practices. In: Oweis, T., Hachum, A. Bruggeman, A. (Eds.), Indigenous Water-Harvesting Systems in West Asia and North Africa. ICARDA, Aleppo.

Pandey, D.N., Gupta, A.K., Anderson, D.M., 2003. Rainwater harvesting as an adaptation to climate change. Current Science 85 (1), 46-59.

Panigrahi, B., Panda, S.N., Agrawal, A., 2005. Water balance simulation and economic analysis for optimal size of on-farm reservoir. Water Resources Management 19, 233-250.

Perry, C.J., 1999. The IWMI water resources paradigm - definitions and implications. Agricultural Water Management 40 (1), 45-50.

Qadir, M., Sharma, B.R., Bruggeman, A., Choukr-Allah, R., Karajeh, F., 2007. Nonconventional water resources and opportunities for water augmentation to achieve food security in water scarce countries. Agricultural Water Management 87 (1), 2-22.

Ramankutty, N., Evan, A.T., Monfredo, C., Foley, J.A., 2008. Farming the planet: 1. Geographic distribution of global agricultural lands in the year 2000. Global Biogeochemical Cycles 22, GB1003.

Rockström, J., 1999. On-farm green water estimates as a tool for increased food production in water scarce regions. Physics and Chemistry of the Earth Part BHydrology Oceans and Atmosphere 24 (4), 375-383.

Rockström, J., Gordon, L., Folke, C., Falkenmark, M., Engwall, M., 1999. Linkages among water vapor flows, food production, and terrestrial ecosystem services. Ecology and Society 3 (2).

Rockström, J., Barron, J., Fox, P., 2002. Rainwater management for increased productivity among small-holder farmers in drought prone environments. Physics and Chemistry of the Earth 27 (11-22), 949-959.

Rockström, J., Lannerstad, M., Falkenmark, M., 2007. Assessing the water challenge of a new green revolution in developing countries. Proceedings of the National Academy of Sciences of the United States of America 104 (15), 6253-6260.

Rost, S. et al., 2008. Agricultural green and blue water consumption and its influence on the global water system. Water Resources Research 44 (9), W09405. 
Senay, G.B., Verdin, J.P., 2004. Developing index maps of water-harvest potential in Africa. Applied Engineering in Agriculture 20 (6), 789-799.

Siebert, S., Döll, P., 2007. Irrigation water use -a global perspective. In: Lozand H.G.J.L., Menzel, L., Schönwiese, C.D. (Eds.), Global Change: Enough Water for all? Universität Hamburg/GEO, pp. 104-107.

Siebert, S. et al., 2005. Development and validation of the global map of irrigated areas. Hydrology and Earth Systems Sciences 9, 535-547.

Smith, S.V., Renwick, W.H., Bartley, J.D., Buddemeier, R.W., 2002. Distribution an significance of small, artificial water bodies across the United States landscape. The Science of the Total Environment 299, 21-36.

Srivastava, R.C., 1996. Design of runoff recycling irrigation system for rice cultivation. Journal of Irrigation and Drainage Engineering 122 (6), 331-335.

Srivastava, R.C., 2001. Methodology for design of water harvesting system for high rainfall areas. Agricultural Water Management 47, 37-53.

Vörösmarty, C.J. et al., 1997. The Storage and aging of continental runoff in large reservoir systems of the world. Ambio 26 (4), 210-219.

Vörösmarty, C.J., Federer, C.A., Schloss, A.L., 1998. Potential evaporation function compared on US watersheds: implications for global-scale water balance and terrestrial ecosystem modeling. Journal of Hydrology 207, 147-169.

Vörösmarty, C.J., Fekete, B.M., Meybeck, M., Lammers, R.B., 2000a Geomorphometric attributes of the global system of rivers at 30-min spatial resolution (STN-30). Journal of Hydrology 237, 17-39.
Vörösmarty, C.J., Fekete, B.M., Meybeck, M., Lammers, R.B., 2000b. A simulated topological network representing the global system of rivers at 30-min spatial resolution (STN-30). Global Biogeochemical Cycles 14, 599-621.

Vörösmarty, C.J. et al., 2003. Anthropogenic sediment retention: major global-scale impact from the population of registered impoundments. Global and Planetary Change 39, 169-190.

Vörösmarty, C.J. et al., 2005. Fresh water ecosystems. Millennium Ecosystem Assessment Vol. 1: Conditions and Trends Working Group Report. Island Press (Chapter 7).

Wisser, D. et al., 2008. Global irrigation water demand: variability and uncertainties arising from agricultural and climate data sets. Geophysical Research Letters 35 , L24408. doi:10.1029/2008GL035296.

Wisser, D., Fekete, B.M., Vörösmarty, C.J., Schumann, A.H., 2009. Reconstructing 20th century global hydrography: a contribution to the Global Terrestrial Network- Hydrology (GTN-H). Hydrology and Earth System Sciences Discussions 6, 2679-2732.

Yang, H., Wang, L., Abbaspour, K.C., Zehnder, A.J.B., 2006. Virtual water highway: water use efficiency in global food trade. Hydrology and Earth System Sciences Discussions 3, 1-26.

Zwart, S.J., Bastiaanssen, W.G., 2004. Review of measured crop water productivity values for irrigated wheat, rice, cotton and maize. Agricultural Water Management 69, 115-133. 